\title{
APPLICATION OF THE VALUE ENGINEERING CONCEPT ON BUILDING CONSTRUCTION PROJECTS IN MALINAU REGENCY IN FACING THE COVID-19 PANDEMIC
}

\author{
Theofilus Yoel Lufung1, Novi Andhi Setyo Purwono², Ilham Poernomo33, \\ Emeliano Maria Gusmão de Oliveira ${ }^{4}$ \\ Department of Civil Engineering, Janabadra University, Indonesia \\ Email: theojoelstudio@gmail.com,novi.andhisp@gmail.com, \\ ilham.purnomo@jana.com, oliveira.emiliano32@gmail.com
}

\begin{tabular}{|c|c|}
\hline ARTICLE INFO & ABSTRACT \\
\hline $\begin{array}{l}\text { Received: } \\
\text { December, } 26^{\text {th }} \\
2021 \\
\text { Revised: } \\
\text { January, 17th } \\
2022 \\
\text { Approved: } \\
\text { January, 18th } \\
2022\end{array}$ & $\begin{array}{l}\text { This study uses data in the form of planning and } \\
\text { implementation data for the construction of the Malinau } \\
\text { District Arts Building. Data development is carried out by } \\
\text { conducting Value Engineering analysis starting from the } \\
\text { project information collection stage, followed by function } \\
\text { analysis using the Law of Pareto. The method used to } \\
\text { analyze the function is F.A.S.T diagram (Function Analysis } \\
\text { System Technique) and Cost to Worth. Followed by the } \\
\text { creativity stage to come up with new alternative designs } \\
\text { that can minimize project costs. The selected design will be } \\
\text { evaluated at the evaluation stage, then the development } \\
\text { stage will be carried out to obtain cost savings on the type } \\
\text { of work that has been analyzed by VE in detail. From the } \\
\text { data analysis at the planning stage, the savings reached } \\
\text { Rp. } 642,220,790, \text { while in the construction phase, savings } \\
\text { of Rp. } 491,286,382 \text {, in } 80 \% \text { of the jobs with the highest } \\
\text { cost items. }\end{array}$ \\
\hline KEYWORDS & $\begin{array}{l}\text { Covid-19 pandemic, Value Engineering, Malinau District } \\
\text { Arts Building, Cost saving }\end{array}$ \\
\hline cc) (†) & $\begin{array}{l}\text { This work is licensed under a Creative Commons } \\
\text { Attribution-ShareAlike } 4.0 \text { International }\end{array}$ \\
\hline
\end{tabular}

\footnotetext{
Theofilus Yoel Lufung, Novi Andhi Setyo Purwono, Ilham Poernomo, Emeliano Maria Gusmão de Oliveira. (2022). Application of the Value Engineering Concept on Building Construction Projects in Malinau Regency in Facing the Covid-19 Pandemic. Journal Eduvest.

How to cite: $\quad$ Vol 2(1): 102-115

E-ISSN: $\quad 2775-3727$

Published by: $\quad$ https://greenpublisher.id/
} 


\section{Theofilus Yoel Lufung, Novi Andhi Setyo Purwono, Ilham Poernomo, Emeliano Maria Gusmão de Oliveira}

\section{INTRODUCTION}

The Covid-19 pandemic has had a negative impact on various sectors in Indonesia, including the construction industry (Sihombing, Malczynski, Jacobson, Soeparto, \& Saptodewo, 2020). Restrictions on social interaction and gatherings of people in public places make various jobs including construction work stop and temporarily delayed. The Covid-19 pandemic has greatly impacted construction projects in Indonesia in general, and in Malinau Regency, North Kalimantan Province in particular, such as policies related to budget rationalization (Idayanti, 2021). The current economic condition demands the use of rational methods and techniques as well as research and application of new techniques by utilizing technological advances in every field (Megawati, 2020). One method that can be used as a cost-saving study is the Value Engineering (VE) method. Value Engineering is a technique for controlling costs that has a large potential for success, by using a value analysis approach to its function (Miles, 2015).

(Dell'Isola, 1997) says value engineering is the application of a value methodology in a project or service that is design or conceptual in nature to achieve added value with three basic elements needed to measure a value, namely function, quality and cost. Value measurement can be done by several methods such as Law of Pareto, Cost-to-Worth, and FAST Diagram. The Malinau District Arts Building is a building construction project built on the Regional Government Road (PEMDA) of Malinau Regency, North Kalimantan Province, with a planned duration of work for 1 (one) fiscal year, namely in the 2020 APBD. The amount of the overall Budget Plan (RAB) this project is Rp. $7,838,791,000.00$ (after tax). The problem in implementing the construction of this project is not taking into account the negative impacts that can occur in the construction world from extraordinary events due to the Covid-19 pandemic which began to spread at the end of 2019 (Ling, 2003).

In this study, we will discuss the application of Value Engineering at the construction stage which has been running until the foundation work before being temporarily suspended due to the Covid-19 pandemic, and being a sampling project if it is carried out during the planning period for the Malinau District Arts Building construction project using the Planning Product data, Plans Planning Cost Budget, Contractor Cost Budget Plan, Terms of Reference, Monthly Certificate, CCO Contract and other supporting data, to see the effectiveness of VE implementation if carried out during the planning period in responding to and anticipating construction constraints caused by the Covid-19 pandemic.

(Szeles, 2019) conducted research on the application of innovation through Value Engineering observations of UK civil engineering contractors, saying that the UK Government has sponsored numerous reports all aimed at securing improvements in the sector. Various guidelines have been developed by organizations such as the Building Research Establishment (BRE), Office of Government Commerce (OGC), Construction Industry Research and Information Association (CIRIA), and the Constructing Excellence (CE) program (Harrison, Bosse, \& Phillips, 2010). In addition to these guidelines, a series of case studies have been published showing that significant improvements can be achieved by implementing value management. (Berawi, Priyatno, Latief, \& Rahman, 2011) in a study on the application of value engineering at the design stage in the Indonesian construction industry stated that the Government has issued a regulation related to Value Engineering through the Minister of Public Works Regulation Number 45/PRT/M/2007 (later revoked and replaced by a Ministerial Regulation No. Public Works and Public Housing Number 22/PRT/M/2018). Based on the regulation, 
development with a building area of more than $12,000 \mathrm{~m} 2$ or more than eight (8) floors, the construction planning service provider is required at the pre-design stage to hold a Value Engineering workshop for 40 (forty) hours, to develop a design concept, by involving the participation of activity managers, construction management service providers, and value engineering service providers. Based on previous research, we can see that there is a research gap, namely Value Engineering which is used to get savings due to the regulation of refocusing the construction sector budget. In other words, the VE applied in previous research is VE that runs under normal moment conditions, not in a special era such as a pandemic. Therefore, in writing this final project, the researcher tries to apply Value Engineering to the construction work of the Malinau art building in the Covid 19 Pandemic era. The need to engineer the value of building components is to control a cost without changing the function value of a building, to make it more economical and efficient. Based on the considerations above, it is necessary to conduct research on the application of the Value Engineering concept to the Malinau District Arts Building construction project in the face of the Covid-19 pandemic.

\section{RESEARCH METHOD}

The research was conducted on the construction project of the Malinau District Arts Building with the research method used is quantitative which is a structured and systematic process consisting of several stages. Each stage is part of the determination to carry out the next stage. Data development is carried out by conducting Value Engineering analysis starting from the stage of collecting information about the project. Then proceed with function analysis using Pareto diagrams, in order to obtain work items that have high costs and those items will be analyzed. The method used to analyze the function is the F.A.S.T diagram (Function Analysis System Technique). Data collection technique is the method used by researchers in obtaining data in the field, namely literature study, or by observation.

\section{RESULT AND DISCUSSION}

\section{A. Application of Value Engineering Concepts at the Planning Stage a. Planning Information Stage}

At this stage, information and data will be collected related to the drawing design, Budget Plan (RAB) and Specifications for the Construction of the Malinau District Arts Building at the Malinau District Public Works Office, from the results of collecting information obtained;

a. The target of the building project: The construction of the Malinau District Arts Building by providing buildings as a means to accommodate cultural activities and services to the community with good quality space.

B. Benefits of building projects: providing facilities that can increase high productivity, good building services.

C. Scope of the building: The development of the Malinau District Arts Building includes a design followed by considering the efforts spent on construction, operation and maintenance. The systems integrated in this building model include Structural, Architectural, and Electrical Mechanical systems.

D. Design The concept of the building is a multi-story tribune building with a reinforced building structure consisting of 3 (three) floors, with a total building of 1450 $\mathrm{m} 2$.

\section{b. Planning Function Analysis}


a. Identification of High Cost Work Items

For Job Identification, it is done by determining the selected work item and Value Engineering is done by using Pareto Analysis (Pareto's Law) which serves to determine the highest cost on the work item that is the object of this research, namely the construction of the Malinau District Arts Building.

The steps in testing Pareto analysis are as follows:

- Sorting jobs from highest cost to least cost.

- Total costs.

- Calculate the percentage cost of each work item using the formula as

following :

$\%$ Job Cost $=$ Job Cost $\mathrm{x} 100$

Total Total Cost

- Calculate the percentage of work components using the following formula:

$\%$ Work Component $=1 \times 100$

Total Work Component

- Calculate the cumulative percentage of total component costs.

- Make a cumulative percentage of total component costs and work components. Create total costs and work components.

Table 1 Recapitulation of Work Weight

\begin{tabular}{|c|c|c|c|}
\hline NO & JOB DESCRIPTION & TOTAL PRICE (Rp) & $\begin{array}{l}\text { WORK } \\
\text { WEIGHT }(\%)\end{array}$ \\
\hline 1 & 2 & 3 & 4 \\
\hline I & Preparatory work & Rp 51.454.887 & 0,72 \\
\hline II & Earth And Sand Works & Rp 179.831 .111 & 2,51 \\
\hline III & Foundation work & Rp 1.841.230.971 & 25,74 \\
\hline IV & Concrete Structure Work & Rp 2.363.121.188 & 33,03 \\
\hline $\mathrm{V}$ & Building Wall Works & Rp 466.899.903 & 6,53 \\
\hline VI & Floor Covering Works & Rp 303.602.031 & 4,24 \\
\hline VII & Ceiling Work & Rp 166.476 .968 & 2,33 \\
\hline VIII & Roof Work & Rp 708.325.021 & 9,90 \\
\hline IX & Fence Work & Rp 319.179.997 & 4,46 \\
\hline$X$ & $\begin{array}{l}\text { Local Culture Architectural Carving } \\
\text { Works }\end{array}$ & Rp 175.264.882 & 2,45 \\
\hline $\mathrm{XI}$ & Painting Job & Rp 215.711.907 & 3,02 \\
\hline XII & Sanitation Work & Rp 145.070.661 & 2,03 \\
\hline XIII & Electrical Installation Works & Rp 100.497.534 & 1,40 \\
\hline XIV & $\begin{array}{l}\text { Frame, Door, Window \& Bouven } \\
\text { Works }\end{array}$ & Rp 53.590.762 & 0,75 \\
\hline \multirow[t]{2}{*}{ XV } & Miscellaneous Jobs & Rp 64.200.000 & 0,90 \\
\hline & Total & Rp 7.154.457.822 & 100 \\
\hline
\end{tabular}

(Source : Data processed)

Tabel above, it can be seen that for Concrete Structural Works, Foundation Works, Roof Works, and Fence Works, the work weight is about 80\% (79.65\%) of all building construction work items. Concrete Structural Work has a work weight of 33.03\%, Foundation work is $25.74 \%$, then Roof Structures is $9.90 \%$, Building Walls is $6.53 \%$, and Fence Works is $4.46 \%$. The 4 (four) components of this work have the potential to be able to analyze the application of the Value Engineering concept because it is a work that was detected with a very large cost of Rp. $5,698,233,074$ 
b. Concrete Structure Work

\begin{tabular}{llll}
\hline IV & & CONCRETE STRUCTURE WORK \\
\hline 1 & Formwork Work & $1.031 .677 .101,97$ & 43,67 \\
\hline 2 & Work. Iron & $813.711 .372,33$ & 34,44 \\
\hline 3 & Work. Cast Concrete & $494.024 .456,21$ & 20,91 \\
\hline 4 & Work. waterproofing & $23.184 .251,79$ & 0,9813 \\
\hline & Sub Total & $2.362 .597 .182,29$ & 100,00 \\
\hline
\end{tabular}

(Source : Data processed)

From Table IV.2 The order of the largest weights in the Concrete Structure Sub-Works is Formwork Work of $43.67 \%$, then Iron Works of $34.44 \%$, Cast Concrete Works of 20\%, and Waterproofing Works of $0.98 \%$.

\section{c. Foundation work}

Table 3 Pareto Foundation Structure Work

\begin{tabular}{llll}
\hline III & FOUNDATION WORK & & \\
\hline \multicolumn{2}{l}{ Mini Pile Job } & $\begin{array}{l}1.146 .159 .237,6 \\
\text { (1) }\end{array}$ & 2,25 \\
\hline $\begin{array}{l}\text { Mount Stone Foundation } \\
\text { Installation }\end{array}$ & $614.873 .456,03$ & 3,39 \\
\hline $\begin{array}{l}\text { Foot Plate Foundation Iron } \\
\text { Work }\end{array}$ & $47.486 .541,31$ & 2,58 \\
\hline Work. Cast Concrete & $23.101 .825,00$ & 2,25 \\
\hline Work. Pass. Formwork & $9.609 .910,80$ & 0,52 \\
\hline & Sub Total & $1.841 .230 .970,7$ & 00,00 \\
& 4 & \\
\hline
\end{tabular}

(Source : Data processed)

From Table 3 The order of the largest weights in the Foundation Structure SubWorks is Mini Pile Work of 62.25\%, Mountain Stone Foundation Works of 33.39\%, Iron Works of $2.58 \%$, Concrete Casting Works of $1.25 \%$, and Formwork Works of $0,52 \%$.

\section{d. Roof Work}

Table 4 Pareto Roof Structure Works

\begin{tabular}{llllllll}
\hline III & ROOF WORK & & & & & & \\
\hline $\begin{array}{l}\text { Tribun-Spandek } \\
\text { covering work }\end{array}$ & roof & 891,70 & $\mathrm{~m}^{2}$ & 145.597 & 129.828 .987 & 18,33 \\
\hline $\begin{array}{l}\text { pack. Pass. Light } \\
\text { Frame Roof }\end{array}$ & Steel & 957,30 & $\mathrm{~m}^{2}$ & 132.000 & 126.363 .600 & 17,84 \\
\hline $\begin{array}{l}\text { Aluminum Foil/Bubble } \\
\text { (Tribune and Entrance) }\end{array}$ & 1017,07 & $\mathrm{~m}^{2}$ & 110.187 & 112.068 .166 & 15,82 \\
\hline $\begin{array}{l}\text { Handlebar Tracks, Knot } \\
\text { Plate, Welding Wire }\end{array}$ & 1778,22 & $\mathrm{~kg}$ & 62.156 & 110.527 .108 & 15,60 \\
\hline $\begin{array}{l}\text { Roof Covering Work } \\
\text { (Entrance and the rest of }\end{array}$ & 125,37 & $\mathrm{~m}^{2}$ & 367.291 & 46.047 .272 & 6,50 \\
Stage 1) & & & & & & & \\
\hline
\end{tabular}


Theofilus Yoel Lufung, Novi Andhi Setyo Purwono, Ilham Poernomo, Emeliano Maria Gusmão de Oliveira

\begin{tabular}{|c|c|c|c|c|c|c|}
\hline III & ROOF WORK & & & & & \\
\hline & Pipe 3" Medium A & 66,00 & $\mathrm{~m}^{\prime}$ & 413.264 & 27.276 .740 & 3,85 \\
\hline & $\begin{array}{l}\text { pack. Pass. Rain Gutter } \\
\text { (Tribune Area) }\end{array}$ & 106,60 & $\mathrm{~m}^{\prime}$ & 194.872 & 20.773 .402 & 2,93 \\
\hline & $\begin{array}{lll}\text { pack. } & \text { Pass. } & \text { Listplank } \\
\text { (Tribune Area) } & \end{array}$ & 404,40 & $\mathrm{~m}^{\prime}$ & 49.316 & 19.943 .483 & 2,82 \\
\hline & Pipe 1.5" Medium A & 122,10 & $\mathrm{~m}^{\prime}$ & 159.866 & 19.520 .040 & 2,76 \\
\hline & Pipe 2" Medium A & 87,35 & $\mathrm{~m}^{\prime}$ & 204.494 & 17.862 .120 & 2,52 \\
\hline & Pipe 4" Medium A & 30,61 & m' & 569.972 & 17.447 .640 & 2,46 \\
\hline & $\begin{array}{l}\text { Listplank Cover Galvalume } \\
\text { Plate } 0.4 \mathrm{~mm} \text { (Roof stage } \\
\text { and entrance) }\end{array}$ & 52,20 & $\mathrm{~m}^{\prime}$ & 317.911 & 16.594 .963 & 2,34 \\
\hline & $\begin{array}{llr}\text { packs. } & \text { Roof } & \text { Ridge } \\
\text { Ornament; } & \text { Bird's } & \text { Head } \\
\text { Carving } & & \\
\end{array}$ & 7,00 & Ls & $\begin{array}{l}2.000 .00 \\
0\end{array}$ & 14.000 .000 & 1,98 \\
\hline & Gording C125 & 107,16 & m' & 100.196 & 10.737.009 & 1,52 \\
\hline & Gutter Plate $0.4 \mathrm{~mm}$ & 27,00 & m' & 298.349 & 8.055 .433 & 1,14 \\
\hline & $\begin{array}{l}\text { Wind Bond and Hard } \\
\text { Needle }\end{array}$ & 107,16 & $\mathrm{~kg}$ & 62.156 & 6.660 .675 & 0,94 \\
\hline & $\begin{array}{lcr}\text { Canopy } & \text { Type } & \text { Roof } \\
\text { Covering } & \text { (Stage } & \text { Area)- } \\
\text { Polycarbonate } & \end{array}$ & 65,60 & $\mathrm{~m}^{2}$ & 70.402 & 4.618 .376 & 0,65 \\
\hline & & \multicolumn{3}{|c|}{ Sub Total } & 708.325 .021 & $\begin{array}{l}100,0 \\
0\end{array}$ \\
\hline
\end{tabular}

(Source : Data processed)

From Table 4 The largest order of weight in the sub-work of roof structures is the work of covering the roof of the tribune with $18.33 \%$, the work of lightweight steel roof truss pairs with $17.84 \%$ and so on.

\section{e. Building Wall Works}

Table 5 Pareto Wall Works

\begin{tabular}{llll}
\hline $\mathrm{V} \quad$ BUILDING WALL WORK & & \\
\hline $\begin{array}{l}\text { Brick Wall Installation Work (1PC : 4 PP, 1/2 brick } \\
\text { thick) }\end{array}$ & 168.770 .066 & 36,15 \\
\hline Work . Plastering Walls (1PC : 3 PP 20 mm Thickness) & 152.313 .326 & 32,62 \\
\hline Work . Wall Repair & 72.958 .011 & 15,63 \\
\hline Work . Pass. Ceramic Wall 15x15cm h $=1.5 \mathrm{~m}$ & 37.317 .267 & 7,99 \\
\hline Work . Gypsum/Kalsiboard Wall Mount 9mm & 35.541 .231 & 7,61 \\
\hline \multicolumn{2}{l}{ Sub-Total } & 466.899 .902 & 100,00 \\
\hline
\end{tabular}

(Source : Data processed) 
From Table 5 The order of the largest weights in the Building Wall Sub-Works is the Red Brick Wall Pairing Work with $36.15 \%$, followed by the Plastering Wall with $32.62 \%$, Finishing Work with $15.63 \%$, Ceramic Wall Pairing Work at $7.99 \%$, and Couples Gypsum wall is $7.61 \%$.

\section{f. Fence Work}

Table 6 Pareto Fence Works

\begin{tabular}{|c|c|c|c|c|c|c|}
\hline \multirow[t]{3}{*}{ IX } & \multicolumn{6}{|l|}{ FENCE WORK } \\
\hline & Fencing Work; Iron Board & & & 2 & & \\
\hline & $(\mathrm{t}=85 \mathrm{~cm})$ & 9,56 & 2 & .720 .000 & 216.403.200 & 7,80 \\
\hline & Galvanized $\quad$ Pipe $\quad$ Fence & & & & & \\
\hline & $\begin{array}{l}\text { Installation Work }(\mathrm{t}=85 \\
\mathrm{cm})\end{array}$ & 86,90 & & 84.137 & 81.518 .982 & 5,54 \\
\hline & $\begin{array}{ll}\text { Under-Stage } & \text { Portable }\end{array}$ & & & & & \\
\hline & $\begin{array}{l}\text { Barrier Folding Fence } \\
\text { Installation Work }\end{array}$ & 0,00 & & 25.156 & 21.257 .814 & ,66 \\
\hline & & Sub 7 & & & 319.179 .996 & 00,00 \\
\hline
\end{tabular}

(Source : Data processed)

From Table 6 The largest order of weight in the Fence Sub-Works is the Work of the Fence Pair; Ulin Board is $67.80 \%$, then Galvanized Pipe Fence Pair Work is 25.54\%, and Under Stage Portable Barrier Folding Fence Work is 6.66\%..2 Functional Analysis of Work Items

The next stage in the application of Value Engineering is the function analysis stage which aims to clarify the main function (basic function) and its supporting function (secondary function). At this stage, identification of functions consisting of verbs (active verbs) and nouns that can be measured (measurable nouns) is carried out. Function identification is carried out on jobs with a large weight and each type is identified. In this project, several high-cost works were identified, namely Concrete Structural Works, Foundation Works, Roofing Works, Wall Works, and Fence Works. Terms of the results of the function analysis obtained from the comparison between costs (costs) and benefits (worth) more than 1 (cost/worth > 1). Where cost is the cost paid for the work item reviewed and worth is the minimum cost for the work item but the function must still be fulfilled.

\section{b. Cost to Worth}

Of the work items that have high costs, a function analysis is carried out which aims to classify the main functions and secondary functions. Comparison between the cost (cost) with the value of benefits (worth) required is also obtained after performing a function analysis. Then alternatives are made at the creative stage and analysis at the next stage of analysis. Based on the results of the cost / worth analysis carried out on each of the work items above, the value of cost / worth $>1$ means that there are unnecessary costs and value engineering can be done (meeting the assumption of feasibility for value engineering).

\section{c. Planning Creative Analysis}

The creative stage is a stage where creative thinking is needed to come up with alternatives that will be used in conducting Value Engineering analysis on the 


\section{Theofilus Yoel Lufung, Novi Andhi Setyo Purwono, Ilham Poernomo, Emeliano Maria Gusmão de Oliveira}

construction components, namely structural and architectural components. These alternatives can be studied from various aspects such as the following:

1) Material or Material

2) Construction Dimension

3) Work Execution Time

4) Work Execution Method

The systematic steps at the stage of value engineering speculation, which deal with finding various alternatives that fulfill the function of the object, that need to be considered are:
a. Focus special attention and thought on functional issues. Come up with some ideas for this purpose with the basic functionality unchanged.
b. What is sought at this stage is an idea. So, it's not a decision about whether or not the idea is accepted.
c. Record all entries, examine whether there are the same or can be combined.
d. Examine whether there is a second function that can be reduced or even removed

\section{d. Analysis Phase and Planning Analysis Results}

In the previous stage, design alternatives have been described, then at this stage an analysis is carried out to choose the best alternative from several alternatives described in the previous stage.

This process deals with selecting and making decisions (judgments) that will give way to development that can be implemented. In order to handle the analysis phase, personnel with a broad spectrum of experience and knowledge are needed related to the object being studied, such as background, familiarity with the object or the like, new techniques in producing or manufacturing, constructability.

1. From the ranking carried out on Roofing Works, the alternative chosen is $0.35 \mathrm{~mm}$ zincalum roof + aluminum voil.Dari perangkingan yang dilakukan pada Pekerjaan Beton Balok, alternatif yang terpilih adalah balok beton bertulang sistem zonasi.

2. From the ranking carried out on Beam Concrete Works, the alternative chosen is reinforced concrete beams with a zoning system.

3. From the ranking carried out on Concrete Plate Work, the alternatives chosen are reinforced concrete and Galvanized Bondek Structural Steel Floor Sheets.

4. From the ranking carried out on Partition Wall Covering Works, the chosen alternative is Kalsiboard.

5. From the ranking carried out on Brick Wall Covering Works, the alternative chosen is Lightweight Brick.

6. From the ranking carried out on the Fence Work, the chosen alternative is $8 \mathrm{~mm}$ Woodplank.

7. From the ranking carried out on Foundation Works, the chosen alternative is the Mini Pile System (Indirect Hydraulic Jacking).

\section{e. Recommendation Stage / Planning Presentation}

This stage is the stage where the work of Value Engineering is presented in the form of graphs of advantages and disadvantages so that it is easy to read the results of the analysis of alternative designs. Alternatives that obtain cost savings occur in roofing, foundations, concrete (floor, columns and beams), walls, and fences. The resulting savings are significant (Rp. 642,220,790) in 80\% of the jobs with the highest cost items, but in terms of technical value, it can be considered because it has benefits not only in terms of costs, but also implementation time, utilization of local resources, durability, and others. Therefore, it is recommended that the initial design related to these works be 
modified according to the chosen alternative. In the analysis of the advantages and disadvantages of roofing work, the alternative that gets the highest rating compared to other alternatives and with the initial design is a $0.35 \mathrm{~mm}$ zincalum roof and aluminum voil.

\section{B. Application of the Value Engineering Concept at the Construction StageConstruction Information Stage}

The information phase of the value engineering process includes::

- Formulating the problem, is the first step before collecting information, there must be clarity and understanding of the problem at hand. In this case, extraordinary events due to the Covid-19 pandemic are the cause of obstacles to building construction which has progressed to the stage of foundation work.

- Gathering information and facts, namely collecting information and formulating answers to questions related to the usability, cost, price and function of the object under investigation. Get to know the object (product) by reviewing functions and recording costs, that is, after digging up information, value engineering activities are continued with the introduction of object facts from various aspects, such as: engineering, and utilization of local resources.

At this stage, information and data related to the design, Shop Drawing, Contractor's RAB and Technical Specifications for the Construction of the Malinau District Arts Building will be collected at the Malinau District Public Works Service, from the results of extracting information obtained;

a. The quality of work must be improved or maintained according to the specifications set by the Owner.

b. The costs incurred are predicted to increase due to restrictions on the number of people (labor) gathered, restrictions on overtime hours, and obstruction of the supply chain for distribution of building materials.

c. The work time will certainly not match the time schedule due to reduced manpower and hampered supply of building materials. Although the submission of a time addendum can be done, the delay in work will result in an increase in the cost of workers' wages.

Creative methods are needed to minimize the adverse effects of the pandemic, before the work has gone far.

\section{Construction Function Analysis}

The same steps in the Planning VE analysis stage, the Construction VE stage are also carried out to identify the selected work items and the Value Engineering application is carried out using Pareto Analysis (Pareto's Law). 
Theofilus Yoel Lufung, Novi Andhi Setyo Purwono, Ilham Poernomo, Emeliano Maria Gusmão de Oliveira

Table 7 Recapitulation of Work Weights for Contractors' RAB

\begin{tabular}{|c|c|c|c|c|}
\hline \multirow{2}{*}{$\begin{array}{l}\text { NO. } \\
1\end{array}$} & JOB DESCRIPTION & \multicolumn{2}{|c|}{ TOTAL PRICE (Rp) } & \multirow[t]{2}{*}{ JOB LOAD $(\%)$} \\
\hline & 2 & \multicolumn{2}{|r|}{3} & \\
\hline $\mathrm{I}$ & Preparatory work & $\mathrm{Rp}$ & 50.041 .994 & 0,70 \\
\hline II & Earth And Sand Works & Rp & 178.225 .003 & 2,50 \\
\hline III & Foundation work & $\mathrm{Rp}$ & 1.840 .573 .297 & 25,83 \\
\hline IV & Concrete Structure Work & $\mathrm{Rp}$ & 2.344 .983 .290 & 32,91 \\
\hline $\mathrm{V}$ & Building Wall Works & $\mathrm{Rp}$ & 457.988 .455 & 6,43 \\
\hline VI & Floor Covering Works & Rp & 302.163 .758 & 4,24 \\
\hline VII & Ceiling Work & $\mathrm{Rp}$ & 165.619 .200 & 2,32 \\
\hline VIII & Roof Work & Rp & 704.014 .380 & 9,88 \\
\hline IX & Fence Work & $\mathrm{Rp}$ & 341.696 .200 & 4,79 \\
\hline $\mathrm{X}$ & $\begin{array}{ll}\text { Local Culture } & \text { Architectural } \\
\text { Carving Works } & \end{array}$ & $\mathrm{Rp}$ & 174.958 .687 & 2,46 \\
\hline XI & Painting Job & $\mathrm{Rp}$ & 208.903 .425 & 2,93 \\
\hline XII & Sanitation Work & $\mathrm{Rp}$ & 143.504 .237 & 2,01 \\
\hline XIII & Electrical Installation Works & $\mathrm{Rp}$ & 98.977 .420 & 1,39 \\
\hline XIV & $\begin{array}{l}\text { Frame, Door, Window \& Bouven } \\
\text { Works }\end{array}$ & $\mathrm{Rp}$ & 52.365 .000 & 0,73 \\
\hline $\mathrm{XV}$ & Miscellaneous Jobs & $\mathrm{Rp}$ & 62.160 .000 & 0,87 \\
\hline \multicolumn{2}{|c|}{$J U M L A H$} & $\mathrm{Rp}$ & 7.126 .174 .346 & 100 \\
\hline \multicolumn{2}{|c|}{$P P N 10 \%$} & $\mathrm{Rp}$ & 712.617 .435 & \\
\hline \multicolumn{2}{|c|}{ TOTAL } & $\mathrm{Rp}$ & 7.838 .791 .780 & \\
\hline
\end{tabular}

(Source: Processed data)

The table above shows that for Concrete Structure Work, Foundation Work, Roof Work, and Fence Work, the work weight is about 80\% (79.84 \%) of all building construction work items. Concrete Structural Work has a work weight of $32.91 \%$, Foundation Structural Work is $25.83 \%$, then Roof Structure Work is $9.88 \%$, Building Wall Works is $6.43 \%$, and Fence Works is $4.79 \%$. The 4 (four) components of this work have the potential to be able to analyze the application of the Value Engineering concept because it is a detected work with a very large cost of Rp. 5,689,255,622. Specifically for Foundation Works at this construction stage, no VE analysis was carried out because the physical progress in the field had reached the Foundation Works stage, before the Covid-19 pandemic caused obstacles to hinder construction progress. Creative Construction analysis

This stage raises alternatives that will be used in conducting Value Engineering analysis on the construction components, namely structural and architectural components. These alternatives can be studied from various aspects such as the following:

1) Materials or materials that can be reached or available in Malinau Regency, to respond to the imposition of restrictions on entry and exit of people and goods.

2) It is hoped that the execution time of the work will not be delayed too long due to construction constraints due to the Covid-19 pandemic.

3) Work Execution Method 
The systematic steps at the stage of value engineering speculation, which deal with finding various alternatives that fulfill the function of the object, that need to be considered are:

a. Generating several ideas for this purpose with the basic function unchanged, but can overcome the problem of the number of workers and implementation time.

b. What is sought at this stage is an idea. So, it's not a decision about whether or not the idea is accepted.

c. Record all entries, examine whether there are the same or can be combined.

d. Examine whether there is a second function that can be reduced or even eliminated.

\section{Analysis Phase and Construction Analysis Results}

This process deals with selecting and making decisions (judgments) that will give way to developments that can be implemented, especially in the face of construction constraints that plague ongoing project work. In order to handle the analysis phase, personnel with a broad spectrum of experience and knowledge are needed related to the object being studied, such as background, work methods, utilization of local resources, familiarity with the object or the like, techniques - teknik baru dalam memproduksi atau pabrikasi, constructability.

The main target to be achieved when the VE process is carried out when construction is already underway is that construction project work affected by the Covid19 pandemic will not have too long a physical progress to be delayed and can still be completed in the 2020 Fiscal Year of the Malinau Regency APBD, maintain the quality of the work, and the benefits of this project can still be felt by the Contractor, Owner, and the user community.

\section{Construction Development Stage}

On the roof work obtained cost savings of Rp. 25,443,119, with the initial Contractor Budget Plan (RAB) of Rp. 704,014,380. In the wall work the chosen alternative cost is Rp. $457,706,838$ while the initial cost is Rp. 457,988,455 which means a savings of IDR $281,616.25$ is obtained. In the column concrete work, a total savings of Rp. 85,827,885. In the slab concrete work, a total savings of Rp. $60,823,762$. In the fencing work the initial cost is Rp. 341,696,199, and the cost of the selected alternative is Rp. 256,726,119, which means a savings of Rp. 84,970,080. The biggest savings were obtained in the concrete work in the beam work section where the savings reached Rp. 233.939,918 from the initial cost of Rp. 1,320,431,667. The recap of savings is seen in the following table:

Table 8 Recapitulation of Savings in Construction Phase Works

\begin{tabular}{llll}
\hline VE . Job Description & Initial Cost (Rp) & \multicolumn{3}{l}{$\begin{array}{l}\text { Alternative Cost } \\
(\mathrm{Rp})\end{array}$} & $\begin{array}{l}\text { Savings } \\
(\mathrm{Rp})\end{array}$ & \\
\hline Wall work & 457.988 .455 & 457.706 .838 & 281.616 \\
\hline Roof Work & 704.014 .380 & 678.571 .260 & 25.443 .119 \\
\hline $\begin{array}{l}\text { Column } \\
\text { Works }\end{array}$ & 360.268 .505 & 274.440 .619 & 85.827 .885 \\
\hline $\begin{array}{l}\text { Beam Concrete } \\
\text { Works }\end{array}$ & 1.320 .431 .667 & 1.086 .491 .748 & 233.939 .918 \\
\hline $\begin{array}{l}\text { Floor Slab Concrete } \\
\text { Works }\end{array}$ & 664.283 .117 & 603.459 .354 & 60.823 .762 \\
\hline Fence Work & 341.696 .199 & 256.726 .119 & 84.970 .080 \\
\hline \multicolumn{1}{c}{ Cost Saving } & & & Rp. 491.286.382 \\
\hline
\end{tabular}

(Source: Processed data) 


\section{Theofilus Yoel Lufung, Novi Andhi Setyo Purwono, Ilham Poernomo, Emeliano Maria Gusmão de Oliveira}

\section{Construction Recommendation / Presentation Stage}

This stage is the stage where the work of Value Engineering is presented in the form of graphs of advantages and disadvantages so that it is easy to read the results of the analysis of alternative designs. The chosen alternative is the one that has the highest profit and loss assessment results and has cost savings results. Alternatives that obtain cost savings occur in roofing, foundations, concrete (floor, columns and beams), walls, and fences. The resulting savings are significant (Rp. 491,286.382) in $80 \%$ of the jobs with the highest cost items, but in terms of technical value, it can be considered because it has benefits not only in terms of costs, but also implementation time, utilization of local resources, durability, and others. Therefore, it is recommended that the initial design related to these works be modified according to the chosen alternative. In the analysis of the advantages and disadvantages of roofing work, the alternative that gets the highest rating compared to other alternatives and with the initial design is a $0.35 \mathrm{~mm}$ zincalum roof and aluminum voil.

\section{THE EFFECT OF THE COVID-19 PANDEMIC ON THE CONSTRUCTION IMPLEMENTATION STAGE}

Several Central Government Regulations to Regional Governments related to the prevention and handling of the Covid-19 pandemic in the scope of construction work resulted in several negative effects, including:

1. Time.

- The activity distance is limited to a minimum of 1.5 meters between workers, which results in a decrease in the speed of completion of work.

- The supply chain is hampered by restrictions on the entry and exit of goods, and the scarcity of goods due to reduced production productivity compared to normal conditions due to restrictions on the number of workers.

- Work that has the potential to be delayed or terminated if it is found that one or more workers experience symptoms or are positive for Covid-19.

2. Cost.

- Additional costs due to the obligation to provide health workers / detection equipment / Covid-19 prevention tools in the construction environment.

- The infrastructure budget ceiling is carried out by refocusing the budget (about $8 \%$ ) for the handling of Covid-19.

- The price of materials has the potential to rise due to the uneven distribution of supplies.

- The price of workers' wages has the potential to increase from the standardization that has been set due to psychological effects / personal safety concerns from the threat of Covid-19 transmission.

\section{Cost saving in the planning and construction stages of the Malinau District Arts Building}

Based on the results of the analysis in this study, it can be seen that the results of this study provide varied results when compared to previous studies. These variations are found in existing work items and enter the analysis stage in value engineering. In some cases, on average there are between 3 to 6 work items that make up the $80 \%$ of the highest total accumulated costs with an average of 4 work items. In this study, 5 work items were included in the analysis. The fence work as the last job has a small additional accumulation but is still within the $80 \%$ accumulation limit, so the fence work items are still being analyzed. It is quite different from other studies such as Shelote et al (2018), Ning (2015), and Reddy \& Polisetty (2016) where the work included in the analysis 
stage mostly includes concrete and foundation work. Structural work in construction management is indeed more expensive in building construction and usually takes quite a long time, so careful and good planning is needed in structural planning work. This is because structural planning will affect the value of the project budget, in addition to influencing other aspects such as structural strength, building durability, and other aspects.

\section{Cost saving at the planning stage}

In this study, it was found that there were unnecessary costs that could be saved. The amount of savings made reached Rp. $642,220,790$ or reaching $8.98 \%$ of the initial value of the project. Financial savings are significant, but this value is in accordance with the maximum value for cutting or refocusing the budget for handling the Covid-19 pandemic. These savings are also able to avoid project losses due to delays caused by construction constraints resulting from the Covid-19 pandemic. This value is also sufficient to increase the profit margin of the contractor or save the project owner's expenses, in the context of this work being a government job, the savings of around 642 million rupiah is a good form of savings and is able to reduce the waste of regional cash expenditures for construction work.

\section{Cost saving at the Construction Stage}

The amount of savings made reached Rp. 491,286,382 or reaching $6.89 \%$ of the initial value of the project. Although the financial savings that occur are significant, this value is quite close to the maximum value for budget cuts or budget refocusing of $8 \%$, and VE can be explored further on other work items so that it can achieve a saving value of $8 \%$. Seeing the construction constraints that occurred due to the Covid-19 pandemic, it is predictable that construction work will be hampered and delayed for quite a long time if VE is not implemented, which will also increase the work costs that will be incurred by the Contractor.

\section{CONCLUSION}

The amount of savings made reached Rp. 491,286,382 or reaching $6.89 \%$ of the initial value of the project. Although the financial savings that occur are significant, this value is quite close to the maximum value for budget cuts or budget refocusing of $8 \%$, and VE can be explored further on other work items so that it can achieve a saving value of $8 \%$. Looking at the construction constraints that have occurred due to the Covid-19 pandemic, it is predictable that construction work will be hampered and delayed for a long time if VE is not implemented, meaning that it will also increase the work costs that will be incurred by the Contractor. From the results of the analysis of value engineering (Value Engineering) in the Planning and Construction stages of the Malinau District Arts Building, the following conclusions can be drawn:

1. The alternative that obtains cost savings at the planning stage is Rp. $642.220,790$ or reaching $8.98 \%$ of the initial planning value.

2. While the alternative that obtains cost savings at the construction stage is Rp. $491,286,382$ or $6.89 \%$ of the initial value of the project.

3. VE carried out at the Planning stage can secure project work if there is a cut or refocusing of the budget for handling the Covid-19 pandemic, which is $8 \%$. 
Theofilus Yoel Lufung, Novi Andhi Setyo Purwono, Ilham Poernomo, Emeliano Maria Gusmão de Oliveira

\section{REFERENCES}

Berawi, M., Priyatno, Herry, Latief, Yusuf, \& Rahman, H. (2011). Application of Value Engineering at Design Stage in Indonesia Construction Industry. Proceeding of the 12th International Conference on QiR. Depok: Universitas Indonesia, Hal, 2121-2126.

Dell'Isola, Alphonse. (1997). Value engineering: Practical applications... for design, construction, maintenance and operations (Vol. 35). John Wiley \& Sons.

Harrison, Jeffrey S., Bosse, Douglas A., \& Phillips, Robert A. (2010). Managing for Stakeholders, Stakeholder Utility Functions, and Competitive Advantage. Strategic Management Journal, 31(1), 58-74.

Idayanti, Soesi. (2021). Issue to the Legal Protection of the Use of the State Budget to Handling Covid-19. Budapest International Research and Critics Institute (BIRCI-Journal): Humanities and Social Sciences, 4(1), 11681177.

Ling, Florence Yean Yng. (2003). Managing the implementation of construction innovations. Construction Management and Economics, 21(6), 635-649.

Megawati, Novienta Yeny. (2020). VALUE ENGINEERING PEKERJAAN PONDASI PADA PROYEK BANGUNAN 3 LANTAI (STUDI KASUS GEDUNG PARKIR DAN PEMBELAJARAN RSUD SYARIFAH AMBAMI RATO EBU BANGKALAN). Untag Surabaya.

Miles, Lawrence D. (2015). Techniques of value analysis and engineering. Miles Value Foundation.

Sihombing, Lukas B., Malczynski, Len, Jacobson, Jake, Soeparto, Hari G., \& Saptodewo, Darma T. (2020). An Analysis of the Spread of COVID-19 and its Effects on Indonesia'S Economy: A Dynamic Simulation Estimation. Available at SSRN 3597004.

Szeles, Zsuzsanna. (2019). ACCOUNTING COST VS FUNCTION COST. Proceedings of FEB Zagreb International Odyssey Conference on Economics and Business, 1(1), 84-92. University of Zagreb, Faculty of Economics and Business. 